\title{
Pengukuran Kesenjangan Digital Menggunakan Metode Deskriptif Berbasis Website
}

\author{
Dini Silvi Purnia ${ }^{1}$, Hidayatul Muhajir ${ }^{2}$, Miftah Farid Adiwisastra $^{3}$, Deddy Supriadi $^{4}$ \\ ${ }^{1}$ Sistem Informasi, STMIK Nusa Mandiri \\ ${ }^{2,3,4}$ Sistem Informasi, Universitas Bina Sarana Informatika \\ E-mail:dini.dlv@nusamandiri.ac.id
}

\begin{abstract}
Jaringan internet saat ini menjadi sesuatu hal yang sangat penting dan hamper semua kalangan menggunakan jaringan ini, Media Digital menjadi sebuah solusi terhadap masalah yang terjadi baik dalam dunia pendidikan ataupun pekerjaan. Kesenjangan digital yang saat ini berlangsung tidak lah mudah untuk di atasi apalagi di kalangan anak remaja yang sudah terbiasa dengan dunia digital sehingga diperlukannya pengukuran untuk memudahkan pendeteksian seberapa jauh seseorang tersebut ketergantungan terhadap internet secara detail. Penelitian ini dilakukan untuk mengukur Kesenjangan Digital dari perilaku kelompok anak muda, mulai dari mengakses internet cara berkomunikasi dan emosional yang sedang dialaminya dengan menghasilkan aplikasi survei berbasis website yang dapat memudahkan dalam mengambil sampel dengan memanfaatkan jaringan Internet sebagai alat yang mudah digunakan, Metode yang digunakan adalah metode deksriptif dengan mengolah data dari kuesioner-kuesioner yang disebar ke beberapa anak muda teruatama kalangan pelajar. Hasil dari penelitian ini adalah Aplikasi survei berbasis website yang dapat mengukur kesenjangan digital.
\end{abstract}

Kata Kunci: kesenjangan digital, safety internet, metode deskriptif

\begin{abstract}
The internet network is now very important and almost all people use this network, Digital Media is a solution to problems that occur both in the world of education or work. The current digital divide is not easy to overcome, especially among teenagers who are accustomed to the digital world, so measurements are needed to make it easier to detect how much a person is dependent on the internet in detail. This research was conducted to measure the digital divide of the behavior of young people, starting from accessing the internet how to communicate and the emotional one they are experiencing by producing a website-based survey application that can make it easier to take samples by utilizing the Internet network as an easy-to-use tool. The method used is Descriptive method by processing data from questionnaires distributed to several young people, especially among students. The result of this research is a website-based survey application that can measure the digital divide.
\end{abstract}

Keywords : digital devide, internet safety, deskriptive method 


\section{INTRODUCTION}

Saat ini internet memang sudah tidak asing bagi mereka yang mempunyai perangkat mobile ataupun teknologi yang bisa berhubungan langsung minimalnya mempunyai Web Browser dengan bantuan jaringan yang terhubung kedalam internet.

Cara yang instan menjadi salah satu daya Tarik bagi para pengguna perangkat digital sekarang, mulai dari kalangan muda hingga tua sekalipun. Namun hal tersebut berbeda dengan kalangan yang berada di pedesaan yang susah dalam mengakses jaringan internet, hasilnya sifat dari internet sendiri yang dikatakan sangat mudah cara pengaksesannya yang tanpa batas menjadi permasalahan sendiri dalam kualitasnya. Kesenjangan digital dapat mengacu kepada kesenjangan antar individu, sosial, pendidikan ekonomi dan kategori demografi lain yang dapat mengacu terhadap pembangunan infrastruktur. Asosiasi Penyelenggara Jasa Internet Indonesia atau biasa yang disebut APJII mengkategorikan karakter area berdasarkan besaran Produk Domestik Bruto disuatu daerah, wilayah urban merupakan daerah administratif yang besar Produk Domestik Bruto seimbang berdasar dari sektor pertanian dan non pertanian. Sedangkan wilayah rural adalah wilayah administratif yang sebagian besar Produk Domestik Bruto berasal dari sektor pertanian, yang dapat menyimpulkan penetrasi internet di wilayah urban mencapai $72,41 \%$ sedangkan rural hamper mencapai setengah populasi yakni 49,49\%. Maka dari perkembangan internet yang semakin pesat dan jangkauan internet yang makin luas masih muncul kesenjangan digital yang terus beriringan dari sumber dayanya yang "melek" terhadap teknologi digital masih dibilang rendah di Negara dunia ketiga atau berkembang. Upaya negara dalam menangani hal tersebut yaitu dengan mengeluarkan paket kebijakan digital dengan $\mathrm{m}$ empercepat penetrasi Internet di seluruh Indonesia, yaitu Program 
Indonesia Digital Netrwoking (IDN) yang dihadirkan sebagai solusi konektivitas nasional.

Kesenjangan Digital diperkenalkan dalam laporan The National Telecomunication and Information Administration (NTIA), yaitu sebuah badan pemerintahan $A S$ (Amerika Serikat) yang mengurusi bidang Telekomunikasi dan Informasi. Dalam postingan (Kompasiana, 2019) mengatakan masalah dalam kesenjangan digital tersebut bukan hanya mengenai infrastruktur saja, melainkan dari perbedaan bagaimana menggunakan internet dengan baik (Safety Internet) yang dapat menunjang desiminasi ilmu pengetahuan, kreativitas dan selanjutnya menjadi alat pengungkit perekonomian dengan memanfaatkan kemudahan internet tanpa batas. Maka dalam hal tersebut penulis merasakan dampak dari penggunaan internet dikalangan urban yang cukup tinggi harus mendominasi penggunaannya dengan baik yang sedikitnya dapat mengatasi kesenjangan digital dalam penggunaan internet.

(Devloper, 2019) memaparkan dalam postingan yang berjudul "jumlah pengguna internet di Indonesia tahun 2019” dalam hal itu menyebutkan pengguna internet di Indonesia mencapai 103 juta orang, mengalahkan negara jepang yang berada diposisi kelima, namun saat ini pengguna internet di dunia di dominasi oleh China, Amerika Serikat, India, Brazil Dan Jepang. Dari pengguna $47,5 \%$ adalah perempuan, sementara 52,5\% adalah laki-laki. Menurut survey tersebut $65 \%$ atau sekitar 86,3 juta pengguna internet di indonesia berada di kepulauan jawa. Dari survey tersebut menunjukan berkembangnya teknologi yang bersifat digital semakin banyak perubahan yang dapat berpengaruh dalam pola pikir serta tingkah laku individu ataupun kelompok yang ketergantungan terhadap cara penggunaanya yang sangat mudah. Ini dikarenakan banyak oknum yang memanfaatkan jaringan internet untuk keperluan dirinya tanpa memperhatikan 
dampak yang terjadi terhadap pengguna yang lain, seperti menyebarkan berita hoax, konten negatif, ujaran kebancian yang menimbulkan keresahan dan perselisihan dari satu kelompok ataupun individu atas dasar hawa nafsu yang dia miliki. ini akan menjadikan pengaruh yang cukup kuat dalam keberlangsungan hidup masyarakat yang semakin lama semakin tervropokasi oleh penyebaran permasalahan di atas . Lalu pertanyaannya apakah kita pernah berfikir apa yang akan terjadi jika fenomena yang akan mengakibatkan potensi perkembangan otak generasi muda Indonesia yang kecenderung ketergantungan dengan internet tanpa mengklarifikasi lingkup tersebut akan menjadi lebih baik untuk menyongsong bertahun-tahun kedepan ? tentu jarang menemukan orang yang berfikir seperti itu. Maka perlu ada penindakan dan updaya dalam menanggulangi hal tersebut secara relefan dan provesional. Terlebih tahun 2019 merupakan penentuan siapa yang akan menjadi penguasa dalam kursi kepresidenan di Indonesia, ini menjadi acuan bagi mereka yang mempunyai niat untuk campur tangan dalam mengelola elektabilitas paslon tertentu dalam mengkampanyeukan perubahan yang di bungkus dalam visi dan misi berharap menjadikan negara ini menjadi lebih baik untuk menyongsong cita-cita bangsa Indonesia yang berdaulat, berkeadilan tanpa memperhatikan ras, suku dan budaya apapun. dalam alur perjalanannya berita ataupun konten negatif yang menyudutkan paslon sudah hadir stengah smester menjelang pemilu itu dilakukan maka tidak jarang kalau melihat anak-anak yang selalu lekat dengan pesta demokrasi tersebut.

Oleh karena itu dengan program yang penulis buat berjudul "Pengukuran Kesenjangan Digital Menggunakan Metode Deskriptif Berbasis Web Studi Kasus MA NU Tasikmalaya" menjadi upaya dalam berkontribusi serta peduli dalam mengubah pola fikir manusia khususnya anak muda yang cenderung ketergantungan terhadap internet dalam menentukan sebuah pilihan. 
Maka harus ada pendekatan dan pengumpulan data mulai dari kebiasaan mereka, cara pengerjaan, maksud serta tujuan dalam penggunaan jaringan internet melalui kebiasaan tersebut, dalam arti memanfaatkan apa yang memang mereka sukai. bentuk survei bisa menjadi cara dalam merealisasikan upaya tersebut untuk mengetahui fakta yang akurat sebelum mensosialisasikan tentang efek negatif seta positif penggunaan jaringan internet sebelum melakukan penindakan.

Dalam Penelitian yang dilakukan oleh (Masril, 2018) menunjukkan bahwa Perkembangan teknologi turut mengubah cara manusia melakukan interaksi dengan satu dan lainnya, dengan meniadakan pertemuan tatap muka. Keadaan ini juga menyebabkan terjadinya perubahan dari nilai, cara berpikir, dan perilaku manusia dalam menyikapi kehidupannya, terutama di kalangan remaja Pola Komunikasi yang terbangun antara remaja dengan orang di sekitarnya, misalnya dengan teman sebaya maupun orang tua juga mengalami perubahan dari sisi kuantitas maupun kualitas. Penelitian ini dilakukan di Universitas Sumatera Utara dengan jumlah responden sebanyak 400 orang dan menggunakan kuesioner.

(Hakim et al., 2018) menunjukkan bahwa kehadiran internet selain berdampak pada interaksi sosial di lingkungan kos ternyata juga memiliki dampak positif dan dampak negaif lainnya seperti dampak klinis, akademis, agama dan ekonomi. Dari penelitian ini juga ditemukan bahwa salah satu komunikasi tidak langsung yang sedang populer yang menjadi aplikasi favorit di kalangan remaja adalah aplikasi instagram.

(Cahyono, 2017) menunjukan dengan adanya media sosial telah mempengaruhi kehidupan sosial dalam masyarakat. Perubahan-perubahan dalam hubungan sosial (social relationships) atau sebagai perubahan terhadap keseimbangan (equilibrium) hubungan sosial dan segala bentuk perubahan-perubahan pada lembaga-lembaga kemasyarakatan didalam 
suatu masyarakat, yang mempengaruhi sistem sosialnya, termasuk didalamnya nilai-nilai, sikap dan pola perilaku diantara kelompok kelompok dalam masyarakat. Perubahan sosial positif seperti kemudahan memperoleh dan menyampaikan informasi, memperoleh keuntungan secara sosial dan ekonomi. Sedangkan perubahan sosial yang cenderung negatif seperti munculnya kelompok - kelompok sosial yang mengatasnamakan agama, suku dan pola perilaku tertentu yang terkadang menyimpang dari norma - norma yang ada.

(Krisnawati, 2015) Dari hasil penelitian ini menunjukan bahwa kalangan Remaja di kota salatiga lebih sering menggunakan media internet dalam melakukan pencarian informasi baik berkaitan dengan ilmu

Dari tingkatan permasalahan di atas yang timbul akibat pengaruh jaringan internet bagi kelompok anak muda sangatlah beragam dan luas, dalam arti bukan hanya dirinya namun sekekliling nyapun dapat terpengaruhi, seperti keluarga, teman, tetangga dan lain pengetahuan dan teknologi maupun untuk bersosialisasi dengan sesamanya. Sedangkan media yang jarang digunakan untuk mencari informasi adalah media Koran. Hal ini menandakan bahwa tingkat ketergantungan remaja di Salatiga terhadap internet dalam mencari informasi sangat tinggi dibandingkan media lainnya. Dengan tingkat ketergantungan penggunaan internet yang tinggi, maka perlu adanya literasi internet yaitu internet sehat untuk pelajar. Hal ini menjadi sangat penting supaya para remaja ketika menggunakan internet dapat menggunakannya sesuai kebutuhan mereka sebagai pelajar yaitu untuk mencari informasi yang menambah wawasan dan pengetahuan.

sebagainya. Maka perlu ada tindakan yang terencana sedemikian rupa yaitu dengan cara mengetahui sampai mana mereka memahami internet beserta penggunaannya, sehubungan dengan hal ini lah perlunya diadakan penelitian mengenai kesenjangan digital dikalangan anak muda, oleh karena 
itu penulis melakukan penelitian mengenai hal ini dengan menghasilkan sebuah aplikasi survey berbasis website untuk mengetahui seberapa besar kesenjangan itu terjadi sehingga hasilnya bisa digunakan oleh pihak terkait dalam hal pembuatan kebijakan dikemudian hari.

\section{MATERIAL DAN METODE}

Metode penelitian yang penulis gunakan dalam penelitian ini adalah penelitian deskriptif, adalah metode penelitian untuk membuat gambaran mengenai situasi atau kejadian, sehingga metode ini dilakukan untuk mengadakan akumulasi data dasar belaka. Namun, dalam pengertian metode penelitian yang lebih luas, dan secara lebih umum sering diberi nama, metode survei. bukan saja memberikan gambaran terhadap fenomenafenomena, tetapi juga menerangkan hubungan, menguji hipotesis-hipotesis, membut predeksi serta mendapatkan makna dan implikasi dari suatu masalah yang ingin dipecahkan. dalam melakukan penelitian untuk pengumpulan data, banyak yang bisa dilakukan misalnya dengan mengedarkan kuesioner, wawancara terstruktur, dan sebagainya.

Pengertian metode deskriptif menurut (sujarweni, 2015) "Penelitian Deskriptif adalah penelitian yang dilakukan untuk mengetahui nilai masing-masing variabel, baik satu variabel atau lebih sifatnya independen tanpa membuat hubungan maupun perbandingan dengan variabel yang lain. Penelitian deskriptif juga merupakan penelitian yang dilakukan dengan tujuan utama untuk memberikan gambaran atau deskripsi tentang suatu keadaan secara objektif."

Dalam penelitian ini, metode deskriptif digunakan untuk menjelaskan tentang penerapan pengendalian internal dalam suatu instansi, pengetahuan serta perilaku orang satu bahkan lebih yang diukur melalui tanggapan mereka dalam menjawab kuesioner yang disajikan. kali ini diterapkan untuk siswa/wi lembaga pendidikan swasta pada studi kasus Madrasah Aliyah Nahdlatul Ulama Kota Tasikmalaya (Manutas). Berikut ini tahapan-tahapan pengumpulan data menggunakan metode Deskriptif : 


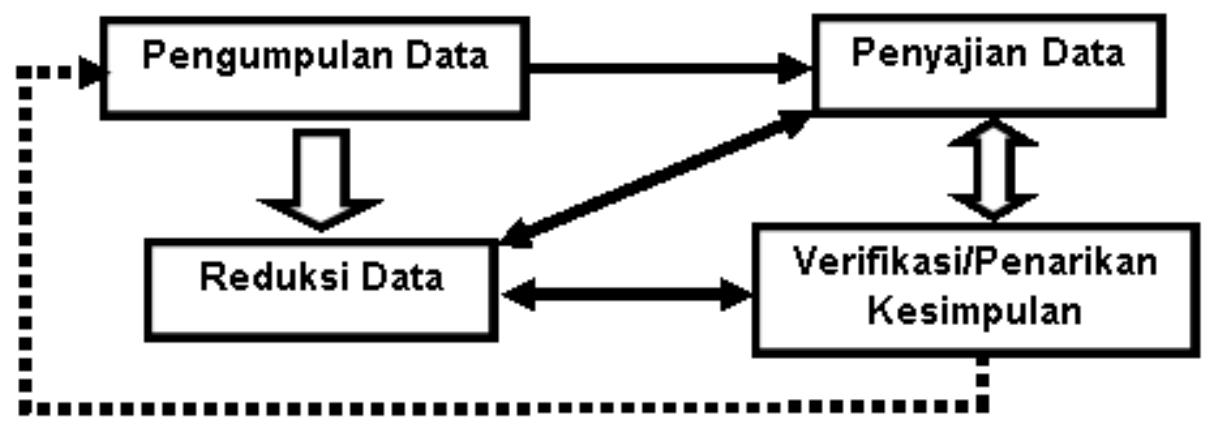

Sumber : (prof. dr. Sugiyono, 2015)

Gambar 1. Alur Pengumpulan Data Deskriptif

Penjelasan dati tahapan-tahapan penelitian menggunakan metode Deskriptif

1. Pengumpulan Data

Menurut (prof. dr. Sugiyono, 2015) metode penelitian kuantitatif dapat diartikan sebagi metode penelitian yang berlandaskan pada filsafat fositivisme, digunakan untuk meneliti pada populasi ayau sampel tertentu, tenik pengambilan sampel pada umumnya dilakukan secara random, pengumpulan data menggunakan instrument penelitian, analisis data bersipat kuantitatif/statistik dengan tujuan untuk menguji hipotesis yang telah ditetapkan.

Dengan wujud seperti itu menurut penulis akan lebih mudah dalam mengambil sampel hasil dari penyebaran kuesioner yang dirspon langsung oleh para siswa Madrasah Aliyah Nahdlatul Ulama Kota Tasikmalaya (Manutas).
2. Penyajian Data

data yang dikumpulkan mula-mula akan disusun otomatis oleh program yang dibuat melalui jawaban yang responden tanggapi. Dalam hal ini bisa disebut dengan metode analitis.

Khusus untuk pengolahan data, dalam hal ini karena menggunakan jenis data kuantitatif, maka analis data yang digunakan adalah statistik deskriptif. Analis jenis ini digunakan guna untuk mempermudah dalam mengelola data atau sampel yang sudah terkumpul sebagaimana adanya tanpa ada perubahan dan menyimpulkan yang berlaku secara umum.

3. Reduksi Data

Yaitu proses pemeriksaan data, menghitung frekuensi data, tabulasi data, klasifikasi data yang akan disesuaikan dengan statistik deskriptif yaitu persen, rata-rata, atau korelasi, memvisualisasikan data table serta 
grafik dan menafsirkan data sesuai

\section{RESULT AND DISCUSSION}

Pada Pelaksanaan penelitian ini penulis menggunakan Metode Deskriptif berikut implementasinya berdasarkan tahapantahapannya :

\subsection{Pengumpulan Data}

Pada Penelitian ini penulis mengumpulkan data dengan beberapa metode dibawah ini:

1. Kuesioner

Kuesioner yaitu teknik pengumpulan data dengan menggunakan daftar pertanyaan mengenai hal-hal yang berhubungan dengan variabel yang diteliti. Jenis kuesioner yang penulis gunakan adalah kuesioner tertutup, yaitu kuesioner yang sudah disediakan jawabannya, alasan penulis menggunakan kuesioner tertutup karena kuesioner jenis ini memberikan kemudahan kepada responden dalam memberikan jawaban, kuesioner tertutup lebih praktis, dan dapat mengimbangi keterbatasan biaya dan waktu penelitian.

\section{Survey}

dengan menggunakan survey peneliti bisa dengan gampang mendapatkan informasi terkait fenomena-fenomena ataupun memperoleh fakta-fakta dari gejala-gejala yang ada dan mencari keterangan-keterangan secara factual, dengan pertanyaan penelitian.

baik tentang institusi sosial, ekonomi dan politik dari suatu kelompok ataupun suatu daera. Metode survey membedah dan menguliti serta mengenal masalahmasalah serta mendapatkan pembenaran terhadap keadaan dan praktik-praktik yang sedang berlangsung.

3. Studi Kasus

Subjek penelitian bisa dikategorikan sebagai individu, kelompok, lembaga, maupun masyarakat. Peneliti ingin mempelajari secara intensif latar belakang serta interaksi lingkungan dari unit-unit sosial yang menjadi subjek. Tujuan studi kasus adalah untuk mengetahui gambaran secara mendetail latar belakang, sifat-sifat serta karakterkarakter yang khas dari kasus, ataupun status dari individu, yang kemudian dari sifat-sifat khas di atas akan jadikan suatu hal yang bersfat umum dan mendasar.

Setelah tahapan pengumpulan data selesai peneliti menentukan jenis data dan kebutuahn system sehingga data yang digunakan sesuai dengan system yang dibangun, pada tahap ini juga dilakukan penganalisaan system sehingga mengetahui kebutuhan dari system tersebut

1. Analisis kebutuhan

merupakan hal yang sangat penting, tanpa terkumpulnya hal tersebut akan berakibat terhambatnya proses pembuatan program, menjadi semakin lama. Maka pada penjelasan kali ini 
penulis akan memaparkan tentang menganalisa kebutuhan fungsional garapan program, dari mulai pengguna maupun system yang akan secara terstruktur.

a. Kebutuhan pengguna

Aplikasi yang penulis buat, terdapat tiga pengguna yang salang berinteraksi namun karakteristik dan kapasitasnya berbeda. Yaitu bagian administrator atau Admin Master dan User atau Responden.

b. Skenario kebutuhan bagian Admin Admin bisa Login program, Mengelola data user dan admin, Dapat mengedit, menghapus Responden, Rekomendasi Daftar Admin dengan Kode, Backup data berupa eksport, Mengelola data pribadi dan Menerima Surat berupa Pesan Digita

c. Skenario kebutuhan bagian User atau Responden

User dapat melakukan Registrasi pengguna., Login program, Mengelola Data Pribadi, Mengisi Kuesioner dan Menerima laporan hasil dari penjumlahan yang lakukan secara otomatis oleh program.

d. Kebutuhan Bagian Admin Agar dapat mengakses program diusahakan super admin harus mempunyai hak akases berupa email dan password yang sudah di daftarkan sebelumnya., Pengguna harus login terlebih dahulu, Program memberikan keluasan untuk super admin berupa tempat yang bisa mengakses dan mengelola semua kebutuhan termasuk data admin dan user. Dan Pengguna harus melakukan logout setelah program selesai digunakan.

e. Kebutuhan Bagian Responden

Agar dapat mengakses program diusahakan super admin harus mempunyai hak akases berupa email dan password yang sudah di daftarkan sebelumnya. Pengguna harus login terlebih dahulu, Responden dapat mengelola data pribadi dan memberikan masukan terhadap super admin mengenai program ataupun hal yang ingin dipertanyakan dan Pengguna harus logout setelah website selesai digunakan

\subsection{Penyajian Data}

Pada penyajian data ini dilakukan perancangan program aplikasi berbasis website dengan langkah-langkah dibawah ini 
1. Struktur Navigasi Halaman Index

a. Halaman Pengunjung

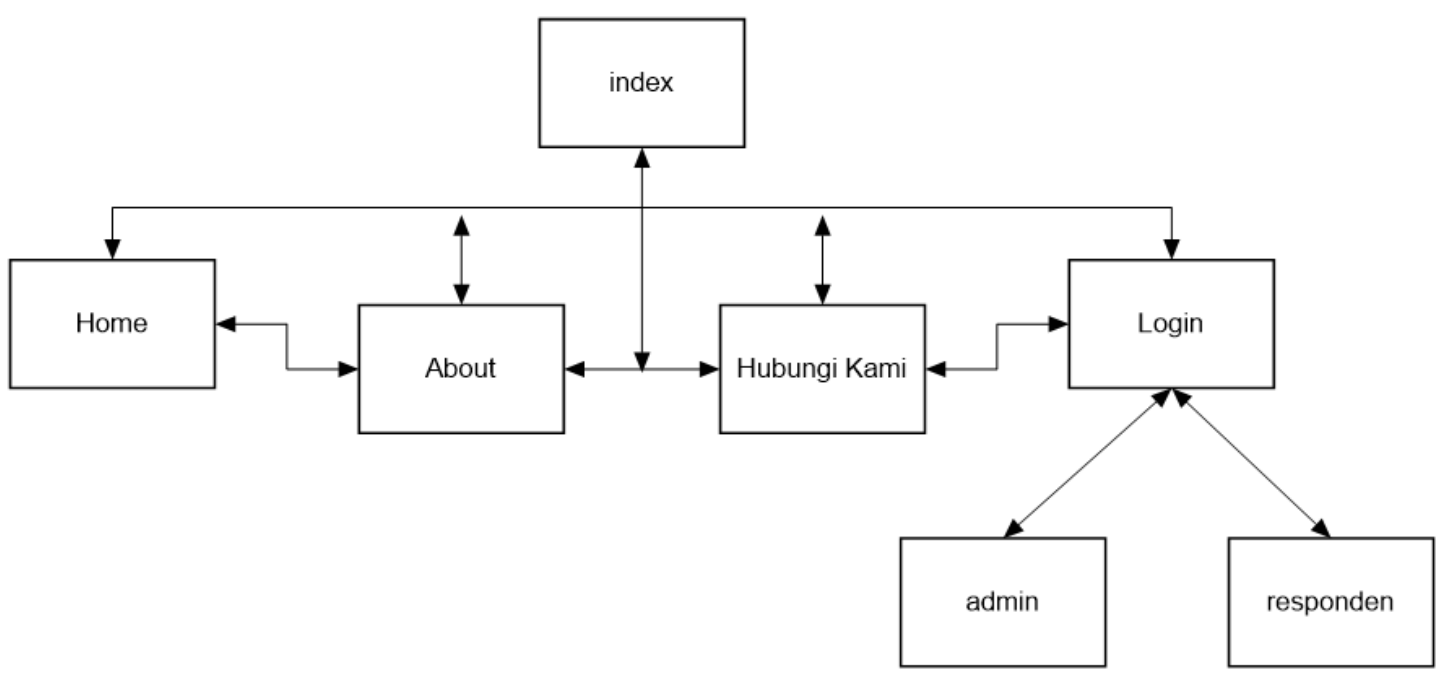

Gambar 2. Struktur Navigasi Index Mепи Utama

b. Struktur Navigasi Halaman Admin

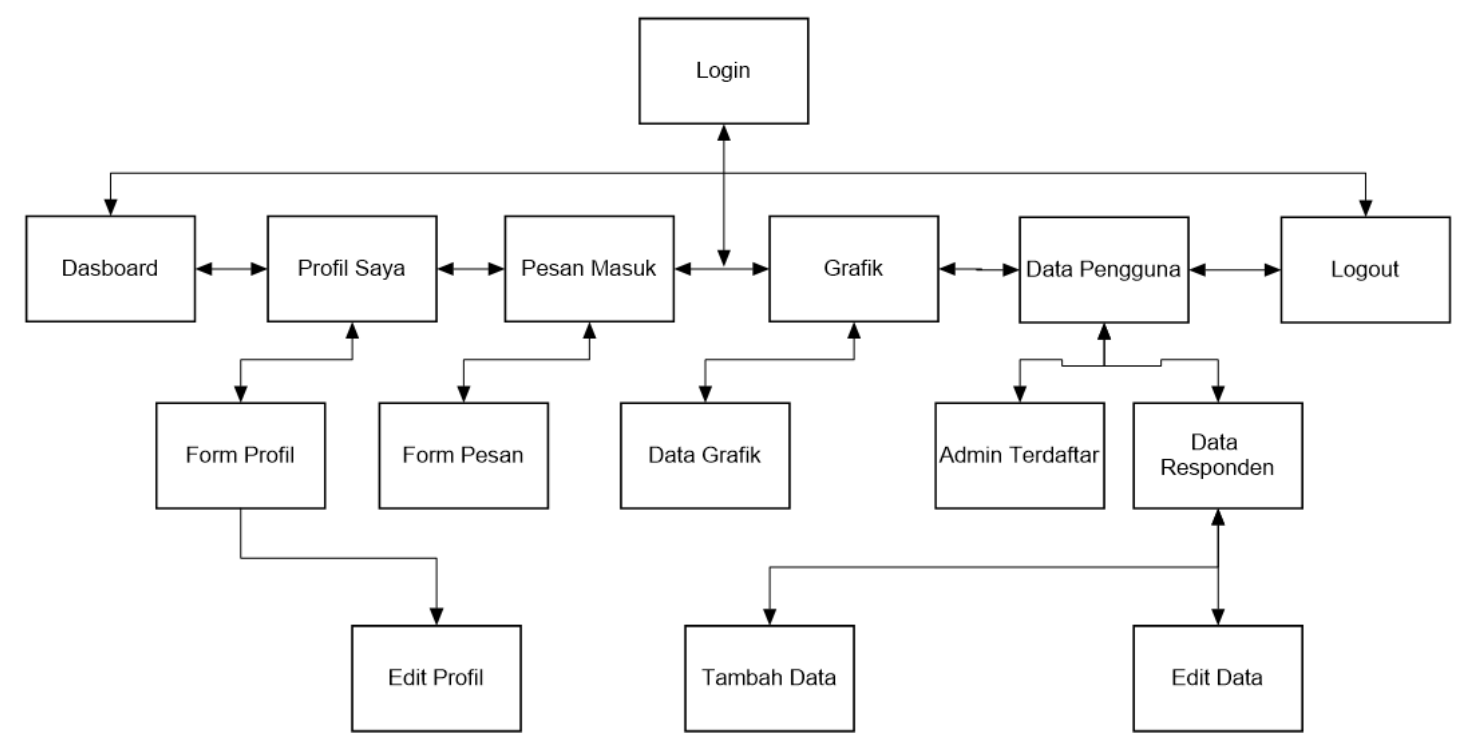

Gambar 3. Struktur Navigasi admin

2. Tampilan Halaman Website

a. Halaman Daftar

Bagi responden yang ingin mempunyai hak akses dan menginput data harus daftar terlebih dahulu untuk dapat login. Form daftar ini tidak diperuntukan untuk kebutuhan admin.

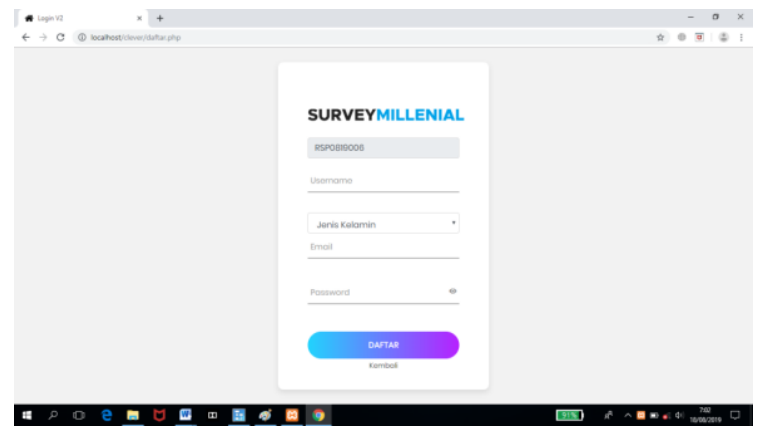

Gambar 4. Antar Muka Halaman Daftar 


\section{b. Halaman Awal}

Halaman awal ini merupakan tampilan antar muka utama bagi para pengguna ataupun pengunjung sekalipun.

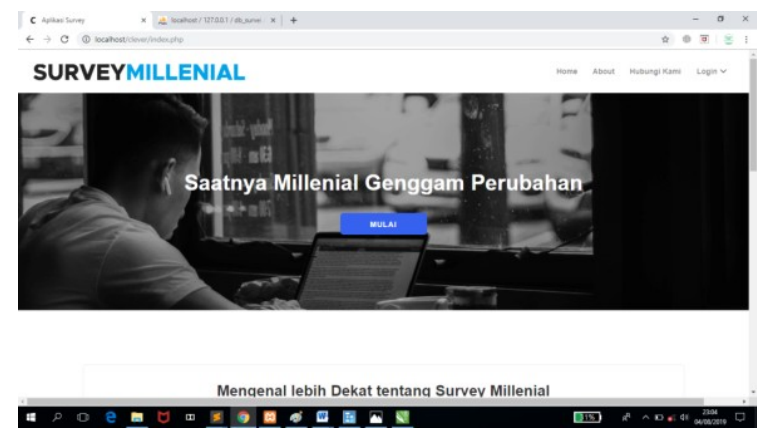

Gambar 5. Antar Muka Halaman Halaman

Awal

c. Halaman Awal Pengguna

Ini merupakan Halaman untuk

pengguna Responden dan Admin

ketika berhasil daftar dan

mendapatkan hak akases Login

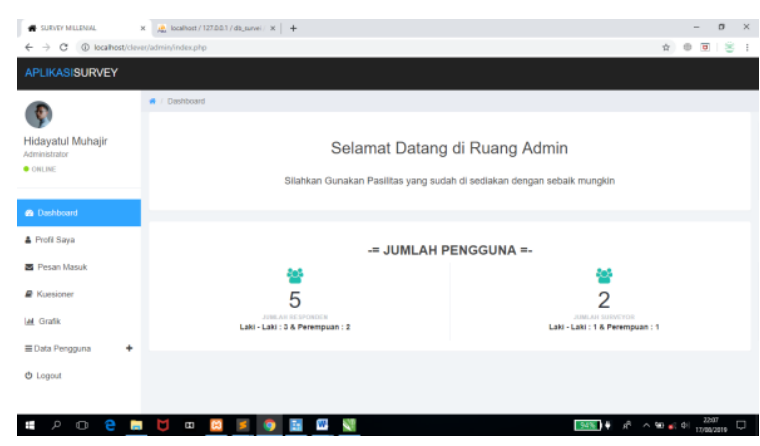

Gambar 6. Antar Muka Halaman Awal
Admin

\section{d. Halaman Profil}

Tampilan ini difungsikan untuk melihat data pribadi pengguna.

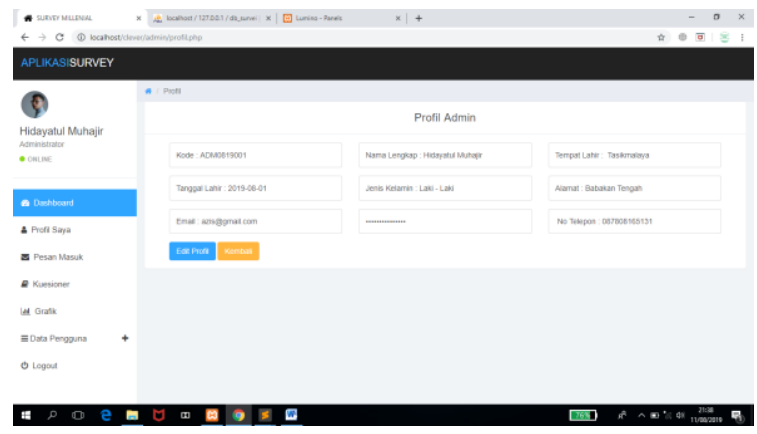

Gambar 7. Antar Muka Halaman Profil

Admin

\subsection{Reduksi Data \\ Pada reduksi data dilakukan pengujian aplikasi survey berbasis website yang telah dirancang dan dibuat, Pengujian terhadap program yang dibuat menggunakan blackbox testing yang fokus terhadap responden.}

Tabel 1. Hasil Pengujian Black Box Testing Halaman Daftar Akun Responden

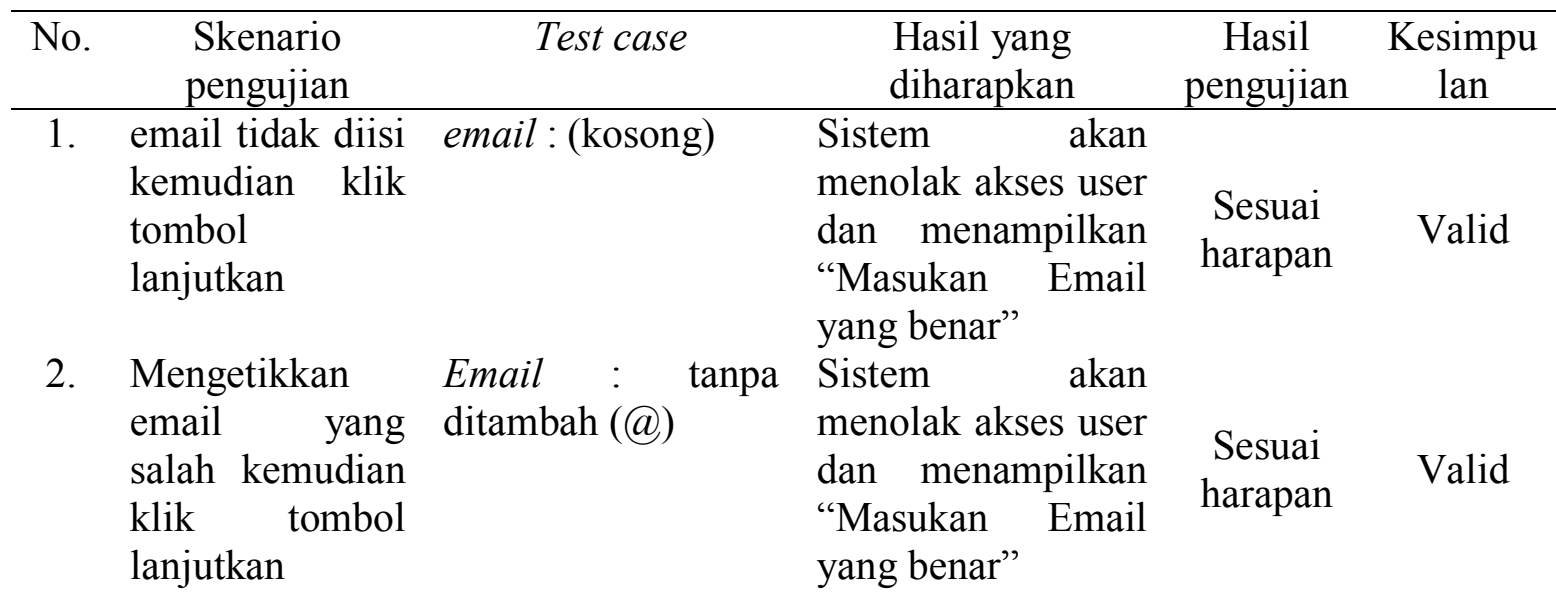


3. Mengetikkan Email: (email) email yang sudah terdaftar kemudian klik tombol lanjutkan

\section{KESIMPULAN}

Kesenjangan digital yang saat ini berlangsung tidak lah mudah untuk di atasi apalagi di kalangan anak remaja yang sudah terbiasa dengan dunia digital sehingga diperlukannya pengukuran untuk memudahkan pendeteksian seberapa jauh seseorang tersebut ketergantungan terhadap internet secara detail. Penelitian ini dilakukan untuk mengukur Kesenjangan Digital dari perilaku kelompok anak muda, mulai dari mengakses internet cara berkomunikasi dan emosional yang sedang dialaminya dengan menghasilkan aplikasi survei berbasis website yang dapat memudahkan dalam mengambil sampel dengan memanfaatkan jaringan Internet sebagai alat yang mudah digunakan, Metode yang digunakan adalah metode deksriptif dengan mengolah data dari kuesioner-kuesioner yang disebar ke
Sistem akan menolak akses user dan menampilkan "Pendaftaran Gagal Email sudah digunakan"

\author{
Sesuai \\ Harapan \\ Valid
}

beberapa anak muda teruatama kalangan pelajar. Hasil dari penelitian ini adalah Aplikasi survei berbasis website yang dapat mengukur kesenjangan digital

\section{UCAPAN TERIMAKASIH}

Penelitian ini dapat dilaksanakan dengan baik berkat bantuan dari berbagai pihak, untuk itu peneliti mengucapkan terima kasih yang sebesar-besar kepada semua pihak yang telah banyak membantu dan memberikan kerjasama yang baik dalam penelitian ini, sehingga peneliti dapat menyelesaikan penelitian ini tepat waktu

\section{REFERENCE}

[1] Ana Puji Astuti, Anike Nurmalita RPS. (2014). Teknologi Komunikasi Dan Perilaku Remaja.

[2] Anang Sugeng Cahyono. (2017). Pengaruh Media Sosial Terhadap Perubahan Sosial Masyarakat.

[3] Ardiansyah, Doni. (2016). Sistem Informasi Pendaftaran Event dengan PHP untuk pandian Skripsi. Cirebon, Jawabarat : CV. ASFA Solution. 
[4] Devlover. (2019). Jumlah Pengguna Internet Di Indonesia Tahun 2019.

[5] Ester Krisnawati, S.Sos., M.I.Kom. (2016). Perilaku Konsumsi Media Oleh Kalangan Remaja Dalam Pencairan Informasi (Studi Kasus Perilaku Remaja Dikota Salatiga Dalam penggunaan Media Dalam Persfektif Teori Ketergantungan Media).

[6] Indrajadi. (2015). Database Design (Case Study All In One) Jakarta PT Elex Media Komputindo

[7] Masril, M \& Mazdalifah. (2018). Pola Kuminkasi Remaja Di Era Digital

[8] Mustaqbal, M. Sidi dkk, (2015). Pengujian Aplikasi Menggunakan Blackbox Testing Boundary Value Analysis. Bandung : Diambil dari jitter,widyatama.ac.id/inde.php/jitter/art icle/view/70/50. (10 April 2017)

[9] Pressman, R.S. (2015). Rekayasa Perangkat Lunak; Pendekatan Praktisi Buku I, Yogyakarta
[10] Prof. Dr. Sugiyono. (2015) Metode Penelitian Pendidikan Pendekatan Kuantitatif, Kualitatif dan R\&D.

[11] Rohi Abdulloh. (2015). Easy \& Simple Web Programing.

[12] Rosa AS dan M. Shalahuddin. (2015). Rekayasa Perangkat Lunak Terstruktur dan Berorientasi Objek. Bandung : INFORMATIKA

[13] Siti Nurina Hakim, Alifatullah Alyu Raj. (2018). Dampak Kecanduan Internet (Internet addiction) pada Remaja.

[14] Sukamto, Rosa Ariani dan Salahudin M .(2016). Rekayasa Perangkat Lunak. Bandung : Informasi Bandung.

[15] Yanto, R. (2016). Manajemen Basis Data Menggunakan MySQL, Yogyakarta : Deepublish 